\title{
Study of Serum Level of Lipoxin A4 in Exercise-Induced Bronchoconstriction in Asthmatic Children
}

\author{
MOHAMED E.A. EL-KASHLAN, M.Sc.*; NABIL M. EL-ESAWY, M.D.*; \\ AHMED M. ABDEL-RAZIK, M.D.* and DINA A. EL-SHAHAT, M.D.** \\ The Departments of Pediatrics* and Clinical Pathology**, Faculty of Medicine, Tanta University
}

\begin{abstract}
Background: Asthma is a chronic lung disease characterized by wheezy chest, resulting from allergic inflammation and hyperresponsivness of the bronchi to various stimuli. Exercise-induced broncho constriction is a common manifestation of asthma in children and adolescents, occurring in up to $90 \%$ of asthmatic children. Lipoxins are the first agents determined to be anti-inflammatory endogenous lipid mediators involved in the resolution of inflammation. Since there is defective lipoxin biosynthesis in patients with severe asthma, we hypothesized that Lipoxin A4 may be related to development of exercise induced bronchoconstriction.
\end{abstract}

Aim of Study: It was to measure serum level of lipoxin A4 before and after exercise to evaluate its role in exercise induced bronchoconstriction in asthmatic children.

Patients and Methods: The study was carried out on fifteen children with mild intermittent or mild persistant asthma with positive response to exercise challenge test and fifteen children with mild intermittent or mild persistant asthma with negative response to exercise challenge test who attended to the outpatient clinic of Chest and Allergic Diseases, Pediatric Department, Tanta University Hospital. Also it was carried on fifteen apparently healthy children with matched age and sex served as a control group. All studied children were subjected to full history taking, thorough clinical examination, plain chest X-ray, pulmonary function tests (FEV 1and PEFR) by spirometer before and after exercise challenge test, eosinophilic count, serum Lipoxin A4 by ELISA before and immediately after exercise challenge test. Data was analyzed by using SPSS.

Results: There was significant more decrease in serum Lipoxin A4 after exercise in asthmatic children with exercise induced bronchoconstriction as compared to asthmatic children without exercise induced bronchoconstriction. Regarding pulmonary function tests (FEV 1 and PEFR), there was significant more decrease in FEV 1 after exercise in asthmatic children with exercise induced bronchoconstriction as compared to asthmatic children without exercise induced bronchoconstriction but, there was no significant difference between

Correspondence to: Dr. Mohamed E.A. El-Kashlan, The Department of Pediatrics, Faculty of Medicine, Tanta University the asthmatic children with exercise induced bronchoconstriction and asthmatic children without exercise induced bronchoconstriction regarding the decrease in PEFR after exercise. And there was no statistical significant difference between subject's sex, age, residence nor BMI.

Conclusion: There was inverse correlation between serum LXA4 levels and a reduction in FEV 1 after exercise in asthmatic children. The demonstration of lower levels of lipoxin A4 in association with exercise induced bronchoconstriction suggest that the development of exercise-induced bronchoconstriction in asthmatic children may be due to reduced endogenous lipoxin biosynthetic capability. This association not affected by ages and sex of patients.

Key Words: Bronchial Asthma - Exercise Induced Bronchoconstriction - Serum Lipoxin A4 by ELISA.

\section{Introduction}

ASTHMA is a common chronic inflammatory disease of the airways that is characterized by variable airway obstruction, hypersecretion of mucus, airway inflammation, and hyperrespo nsiveness of the airways [1].

There is wide geographical variation in the prevalence of asthma and allergic conditions worldwide, with substantial differences seen between low- and high-income countries, and between urban and rural communities [2].

In susceptible individuals, airway inflammation may cause recurrent or persistent bronchospasm, which causes symptoms that include wheezing, breathlessness, chest tightness, and cough, particularly at night $[3]$.

Exercise-induced bronchoconstriction is a common manifestation of asthma in children and adolescents, occurring in up to $90 \%$ of asthmatic children. However, the reasons exercise induces bronchoconstriction in only a subgroup of asthmatic children are not clear [4] 
Lipoxins are the first agents determined to be anti-inflammatory endogenous lipid mediators involved in the resolution of inflammation [5]

Lipoxins and their analogs could help the resolution of inflammation by different mechanisms, including inhibition of the biosynthesis of proinflammatory lipid mediators, cytokine and chemokine production, leuko-cyte recruitment and activation, stimulation of the clearance of apoptotic leukocytes, and blocking of edema formation [6]

It has been reported that a decrease in LXA4 occurs in severe asthma and downregulation of the expression of genes involved in LXA4 formation has been observed in lung biopsies from severe asthmatics [7].

Lipoxin A4 (LXA4) suppresses airway hyperresponsiveness and pulmonary inflammation through anti-inflammatory receptors, namely ALX/ FPR2 receptors, expressed on both leukocytes and airway epithelial cweells [8].

\section{Aim:}

It was to measure serum level of lipoxin A4 before and after exercise to evaluate its role in exercise induced bronchoconstriction in asthmatic children.

\section{Patients and Methods}

The case control study was conducted on 30 asthma cases and 15 non asthma control cases. Asthmatic patients who attended to the outpatient clinic of Chest and Allergic Diseases, Pediatric Department, Tanta University Hospital during the period from April, 2017 to April, 2018 (aged from614 years), only children who strictly fulfilled the criteria for mild intermittent or mild persistant asthma were involved in an attempt to prevent the severity of disease from being a confounding factor [9]. The children were stable and in between attacks at performance of the study.

Exclusion criteria: Children with moderate to severe asthma, children who have an upper or lower airway infection or an asthma exacerbation within six weeks before sample, children who have taken antihistamines during the week before exercise challenge and children who had used inhaled corticosteroids within the last two weeks were generally excluded from the study.

Both patients and control groups were subjected to the following: Full history taking, clinical examination, CBC (Eosinophil count), Plain X-ray chest, Lipoxin A4 levels in the serum by ELISA before and immediately after the exercise test, Pulmonary function tests (FEV 1 and PEFR) by spirometry before and after ECT. At least three technically accepted maneuvers were performed and the best value was recorded before exercise [10] and children had undergone serial PFT measurements at immediately ( $0 \mathrm{~min}$.), 5,10,15,20, and 30 minutes after exercise was stopped. The lowest FEV 1 and PEFR values were recorded within 30 minutes after exercise and were expressed as the post-exercise values and were compared to baseline [11]. Exercise challenge was considered positive if FEV 1 dropped $10 \%$ or more comparing baseline values at any two consecutive time point recordings according to the definition supported by most experts [12].

Two ml venous blood was taken from every subject included in this study just before and immediately after the exercise test using complete aseptic technique with sterilization using $70 \%$ alcohol. The needle of the syringes was then removed and each sample was allowed to pass gently along the wall of clean plain dry tube labeled with patient name.

The blood was allowed to clot at room temperature from 10-20mins. Centrifugation was done for 20min. at the speed of 2000-3000r.p.m. supernatant was removed by means of clean dry tube for determination of Lipoxin A4 (LXA4) level by ELISA kit which is based on the principle of double-antibody sandwich technique to detect Human (LXA4) used only for research purposes. Specimen was kept in $\left(-20^{\circ} \mathrm{C}\right)$ and repeated freeze-thaw cycles were avoided. This ELISA kit is for in-vitro diagnostic use.

Statistical presentation and analysis of the present study was conducted using the mean, standard deviation, student $t$-test, Chi-square, F-test (ANOVA), Pearson coefficient, Spearman coefficient, Paired t-test by IBM SPSS software package version 20. (Armonk, NY: IBM Corp) [13] with $p$ $<0.05$ means significance.

\section{Results}

This study was conducted on 30 cases with clinically definite asthma and 15 non asthma control cases, both patients and control were cross matched for age and sex.

Table (1) presents the demographics and laboratory data of the case control study population as regard age, sex, residence, BMI, family history of atopic diseases and eosinophil \%. It show no significant difference between the asthmatic children 
and controls as regard demographics data as age, sex, residence, BMI and esinophils \% ( $p$-value $>0.05$ ) but show significant increase in family history of atopic diseases in asthmatic children as compared to controls ( $p$-value $<0.05$ ).

There was significant increase of family history of atopic diseases in asthmatic children with EIB and asthmatic children without EIB as compared to controls and there was no significant difference between asthmatic children with EIB and asthmatic children without EIB as regard to family history of atopic diseases as shown in Fig. (1).

There was significant decrease of FEV1 before exercise in asthmatic children with EIB and without EIB as compared to controls and there was significant decrease of FEV1 before exercise in asthmatic children with EIB as compared to asthmatic children without EIB.

There was significant more decrease in FEV1 after exercise in asthmatic children with EIB as compared to asthmatic children without EIB but there was no significant difference between the before exercise level and after exercise as regard to FEV1 in control group.

There was no significant difference between the asthmatic children with EIB and asthmatic children without EIB as regard to the decrease in PEFR after exercise as shown Table (3).
There was significant more decrease in serum LXA4 after exercise in asthmatic children with EIB as compared to asthmatic children without EIB as shown in Table (4).

There was significant positive correlation between serum LXA4 and FEV1 but there was no significant correlation between serum lipoxin A4 levels and eosinophil counts and PEFR. as shown in Table (5).

There was an inverse correlation between serum LXA4 levels and a reduction in FEV1after exercise as shown in Fig. (2).

There was a significant decrease in FEV1 after exercise as compared to FEV1 before exercise in both mild intermittent and mild persistant asthmatic children with more decrease in mild persistant asthmatic children as shown in Table (6).

There was a significant decrease in PEFR after exercise as compared to PEFR before exercise in both mild intermittent and mild persistent asthmatic children with more decrease in mild persistant asthmatic children as shown in Table (7).

There was a significant decrease in serum LXA4 after exercise as compared to serum LXA4 before exercise in both mild intermittent and mild persistant asthmatic children with more decrease in mild persistant asthmatic children as shown in Table (8).

Table (1): Comparison between the asthmatic children and controls according to demographic data and laboratory data

\begin{tabular}{|c|c|c|c|c|c|c|c|c|}
\hline & \multicolumn{2}{|c|}{$\begin{array}{l}\text { Asthmatic children } \\
\text { with EIB }(n=15)\end{array}$} & \multicolumn{2}{|c|}{$\begin{array}{l}\text { Asthmatic children } \\
\text { without EIB }(n=15)\end{array}$} & \multicolumn{2}{|c|}{$\begin{array}{l}\text { Control group } \\
\qquad(\mathrm{n}=15)\end{array}$} & \multirow{2}{*}{$\begin{array}{l}\text { Test of } \\
\text { Sig. }\end{array}$} & \multirow{2}{*}{$p$} \\
\hline & No. & $\%$ & No. & $\%$ & No. & $\%$ & & \\
\hline \multicolumn{9}{|l|}{ Sex: } \\
\hline Male & 6 & 40 & 7 & 46.7 & 8 & 53.3 & $\chi^{2}=$ & \multirow[t]{2}{*}{0.765} \\
\hline Female & 9 & 60 & 8 & 53.3 & 7 & 46.7 & 0.536 & \\
\hline \multicolumn{9}{|l|}{ Age: } \\
\hline Range & \multirow{2}{*}{\multicolumn{2}{|c|}{$\begin{array}{c}7.0-15.0 \\
9.87 \pm 2.50\end{array}$}} & \multicolumn{2}{|c|}{$7.0-14.0$} & \multicolumn{2}{|c|}{$7.0-14.0$} & $\mathrm{~F}=$ & \multirow[t]{2}{*}{0.468} \\
\hline Mean \pm SD & & & & & & 29 & 0.772 & \\
\hline \multicolumn{9}{|l|}{ Residence: } \\
\hline Rural area & 10 & 66.7 & 7 & 46.7 & 8 & 53.3 & $\chi^{2}=$ & \multirow[t]{2}{*}{0.533} \\
\hline Urban area & 5 & 33.3 & 8 & 53.3 & 7 & 46.7 & 1.260 & \\
\hline \multicolumn{9}{|l|}{$B M I(\mathrm{~kg} / \mathrm{m} 2)$ : } \\
\hline Range & \multirow{2}{*}{\multicolumn{2}{|c|}{$\begin{array}{c}14.90-24.70 \\
19.18 \pm 2.81\end{array}$}} & \multirow{2}{*}{\multicolumn{2}{|c|}{$\begin{array}{l}14.10-25.0 \\
17.68 \pm 2.89\end{array}$}} & \multirow{2}{*}{\multicolumn{2}{|c|}{$\begin{array}{l}15.50-18.90 \\
17.59 \pm 0.91\end{array}$}} & $\mathrm{~F}=$ & \multirow[t]{2}{*}{0.136} \\
\hline Mean \pm SD & & & & & & & 2.095 & \\
\hline \multicolumn{9}{|l|}{ Family history: } \\
\hline Negative & 5 & 33.3 & 2 & 13.3 & 15 & 100 & \multirow{2}{*}{$\begin{array}{l}\chi^{2} \\
24.723 *\end{array}$} & \multirow[t]{2}{*}{$<0.001 *$} \\
\hline Positive & 10 & 66.7 & 13 & 86.7 & 0 & 0.0 & & \\
\hline Sig. bet. Grps & \multicolumn{7}{|c|}{$\mathrm{FE}_{p_{1}=0.390, p 2<0.001^{*}, p 3<0.001^{*}}$} & \\
\hline \multicolumn{9}{|l|}{ Esinophils (\%): } \\
\hline Range & \multirow{2}{*}{\multicolumn{2}{|c|}{$\begin{array}{c}0.50-5.0 \\
1.79 \pm 1.09\end{array}$}} & \multirow{2}{*}{\multicolumn{2}{|c|}{$\begin{array}{c}1.0-4.0 \\
2.25 \pm 1.14\end{array}$}} & \multirow{2}{*}{\multicolumn{2}{|c|}{$\begin{array}{c}0.50-2.0 \\
1.33 \pm 0.49\end{array}$}} & $\mathrm{H}$ & \multirow[t]{2}{*}{0.099} \\
\hline Mean \pm SD. & & & & & & & 4.621 & \\
\hline
\end{tabular}

Data are represented as mean $\pm \mathrm{SD}$ and range. 
Table (2): FEV1 in asthmatic children and controls before and after exercise.

\begin{tabular}{|c|c|c|c|c|c|}
\hline FEV1 & $\begin{array}{l}\text { Asthmatic children } \\
\text { with EIB }(n=15)\end{array}$ & $\begin{array}{l}\text { Asthmatic children } \\
\text { without EIB }(n=15)\end{array}$ & $\begin{array}{l}\text { Control group } \\
(\mathrm{n}=15)\end{array}$ & $\begin{array}{l}\text { Test of } \\
\text { Sig. }\end{array}$ & $p$ \\
\hline \multicolumn{6}{|l|}{ Before exercise: } \\
\hline Range & $83.0-94.0$ & $86.0-115.0$ & $92.0-109.0$ & \multirow{2}{*}{$\begin{array}{l}\mathrm{F}= \\
16.953^{*}\end{array}$} & \multirow[t]{2}{*}{$<0.001 *$} \\
\hline Mean \pm SD. & $86.53 \pm 2.97$ & $92.27 \pm 7.23$ & $97.73 \pm 4.71$ & & \\
\hline Sig. bet. Grps & \multicolumn{3}{|c|}{$p 1=0.013^{*}, p 2<0.001 *, p 3<0.019^{*}$} & & \\
\hline After exercise: & & & & \multirow{3}{*}{$\begin{array}{l}\mathrm{F}= \\
98.134^{*}\end{array}$} & \multirow{3}{*}{$<0.001 *$} \\
\hline Range & $60.0-75.0$ & $80.0-106.0$ & $89.0-106.0$ & & \\
\hline Mean \pm SD. & $68.60 \pm 4.9$ & $87.47 \pm 6.69$ & $95.67 \pm 4.35$ & & \\
\hline Sig. bet. Grps & \multicolumn{3}{|c|}{$p 1=0.001 *, p 2<0.001 *, p 3<0.001 *$} & & \\
\hline Change & $\downarrow 17.93 \pm 3.17$ & $\downarrow 4.80 \pm 2.08$ & $\downarrow 2.07 \pm 1.44$ & \multirow{2}{*}{$\begin{array}{l}\mathrm{H}= \\
34.659^{*}\end{array}$} & \multirow[t]{2}{*}{$<0.001^{*}$} \\
\hline Sig. bet. Grps & \multicolumn{3}{|c|}{$p 1=0.001 *, p 2<0.001 *, p 3<0.024^{*}$} & & \\
\hline
\end{tabular}

Table (3): Change in PEFR in asthmatic children after exercise.

\begin{tabular}{lcccc}
\hline $\begin{array}{l}\text { PEFR } \\
\text { (\% of predicted) } \\
\text { (change) }\end{array}$ & $\begin{array}{c}\text { Asthmatic } \\
\text { children } \\
\text { with EIB } \\
(\mathrm{n}=15)\end{array}$ & $\begin{array}{c}\text { Asthmatic } \\
\text { children } \\
\text { without EIB } \\
(\mathrm{n}=15)\end{array}$ & $\mathrm{u}$ & $p$ \\
\hline Range & $-2.0-40.0$ & $0.0-11.0$ & 76.50 & 0.132 \\
Mean \pm SD. & $8.73 \pm 10.83$ & $3.27 \pm 2.81$ & 7.50 & \\
\hline
\end{tabular}

Table (4): Change in serum LXA4 in asthmatic children after exercise.

\begin{tabular}{lcccc}
\hline $\begin{array}{l}\text { Serum } \\
\text { LXA4 }(\mathrm{ng} / \mathrm{ml}) \\
(\text { change })\end{array}$ & $\begin{array}{c}\text { Asthmatic } \\
\text { children } \\
\text { with EIB } \\
(\mathrm{n}=15)\end{array}$ & $\begin{array}{c}\text { Asthmatic } \\
\text { children } \\
\text { without EIB } \\
(\mathrm{n}=15)\end{array}$ & $\mathrm{u}$ & $p$ \\
\hline Range & $47.34-161.22$ & $27.63-135.32$ & & \\
Mean \pm SD. & $94.77 \pm 35.43$ & $55.50 \pm 31.46$ & $36.0 *$ & $0.002^{*}$ \\
\hline
\end{tabular}

Table (5): Correlation between serum LXA4 and different parameters in total asthmatic children $(n=30)$.

\begin{tabular}{cccccccc}
\hline & \multicolumn{6}{c}{ Serum LXA4 (ng/ml) } \\
\cline { 2 - 7 } & \multicolumn{2}{c}{ Before } & \multicolumn{2}{c}{ After } & \multicolumn{2}{c}{ Change } \\
\cline { 2 - 7 } & $r$ & $p$ & $r$ & $p$ & $r_{s}$ & $p$ \\
\hline $\begin{array}{c}\text { FEV1 (\% of } \\
\text { predicted) }\end{array}$ & -0.237 & 0.208 & $0.698^{*}$ & $<0.001^{*}$ & $0.470^{*}$ & $0.009^{*}$ \\
$\begin{array}{c}\text { PEFR (\% of } \\
\text { predicted) }\end{array}$ & -0.037 & 0.847 & 0.435 & 0.061 & 0.146 & 0.442 \\
$\begin{array}{c}\text { Esinophils } \\
(\%)\end{array}$ & -0.110 & 0.561 & & & & \\
\hline
\end{tabular}

Table (6): FEV1 in children with mild intermittent asthma and children with mild persistant asthma before and after exercise.

\begin{tabular}{|c|c|c|c|c|}
\hline & \multicolumn{2}{|c|}{ FEV1 (\% of predicted) } & \multirow[b]{2}{*}{$t$} & \multirow[b]{2}{*}{$p$} \\
\hline & $\begin{array}{l}\text { Before } \\
\text { exercise }\end{array}$ & $\begin{array}{l}\text { After } \\
\text { exercise }\end{array}$ & & \\
\hline \multicolumn{5}{|c|}{ Mild intermittent: } \\
\hline Range & $83.0-115.0$ & $60.0-106.0$ & $6.637^{*}$ & $<0.001 *$ \\
\hline Mean \pm SD & $90.45 \pm 7.0$ & $79.80 \pm 11.67$ & & \\
\hline \multicolumn{5}{|l|}{ Mild persistant: } \\
\hline Range & $83.0-95.0$ & $62.0-89.0$ & $5.511^{*}$ & $<0.001 *$ \\
\hline Mean \pm SD. & $87.30 \pm 3.40$ & $74.50 \pm 9.81$ & & \\
\hline
\end{tabular}

Table (7): PEFR in children with mild intermittent asthma and children with mild persistant asthma before and after exercise.

\begin{tabular}{llllll}
\hline & \multicolumn{2}{c}{ PEFR (\% of predicted) } & & $p$ \\
\cline { 2 - 3 } & $\begin{array}{l}\text { Before } \\
\text { exercise }\end{array}$ & $\begin{array}{c}\text { After } \\
\text { exercise }\end{array}$ & & \\
\hline $\begin{array}{l}\text { Mild intermittent: } \\
\text { Range }\end{array}$ & $44.0-91.0$ & $30.0-85.0$ & $4.607^{*}$ & $<0.001^{*}$ \\
Mean \pm SD. & $69.25 \pm 14.18$ & $65.50 \pm 15.30$ & & \\
Mild persistant: & & & & \\
$\quad \begin{array}{l}\text { Range } \\
\text { Mean } \pm \text { SD. }\end{array}$ & $51.0-88.0$ & $35.0-88.0$ & $2.643 *$ & $<0.001^{*}$ \\
\hline
\end{tabular}

Table (8): Serum LXA4 in children with mild intermittent asthma and children with mild persistant asthma before and after exercise.

\begin{tabular}{lccccc}
\hline & $\begin{array}{c}\text { Serum LX4A } \\
\text { before exercise after exercise }\end{array}$ & $\begin{array}{c}\text { Serum LXA4 } \\
\text { bild intermittent: }\end{array}$ & & $p$ \\
$\quad$ Range & $70.62-185.43$ & $14.36-84.41$ & $6.851 *$ & $<0.001^{*}$ \\
Mean \pm SD. & $114.94 \pm 39.29$ & $36.41 \pm 18.75$ & & \\
Mild persistant: & & & & & \\
$\quad$ Range & $69.50-175.40$ & $15.55-59.92$ & $8.023^{*}$ & $<0.001^{*}$ \\
Mean \pm SD. & $112.0 \pm 31.84$ & $39.46 \pm 14.81$ & & \\
\hline
\end{tabular}

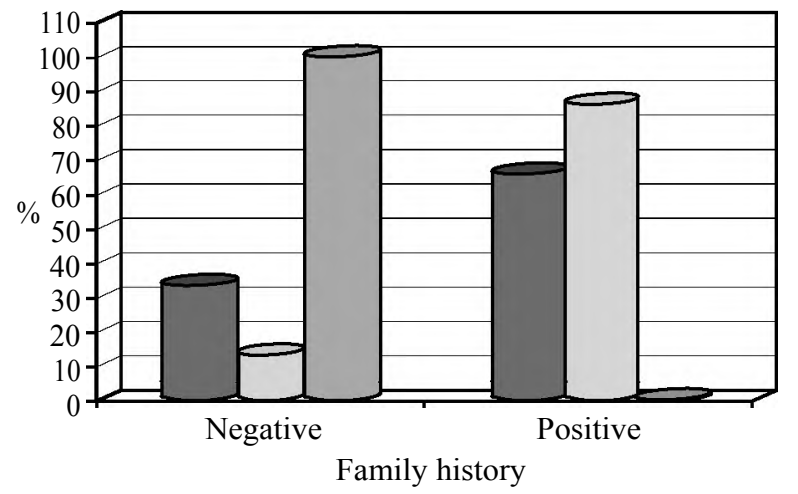

Asthmatic children $\square$ Asthmatic children with EIB without EIB

Control group

Fig. (1): Comparison between the asthmatic children and controls according to family history of atopic diseases. 


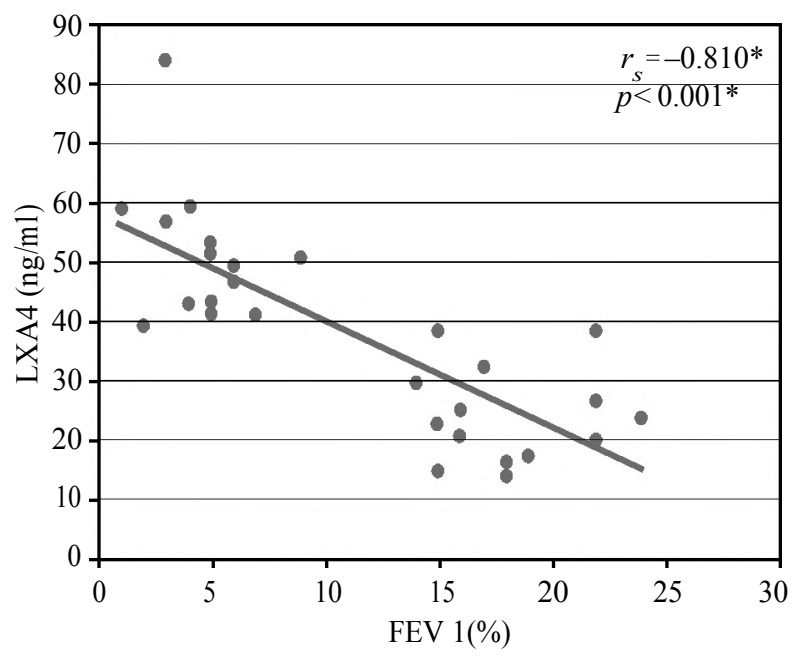

Fig. (2): Correlation between FEV1 (Change) and LXA4 (after exercise) in total asthmatic children $(n=30)$.

\section{Discussion}

LXA4 mimetics can significantly inhibit features of allergic pulmonary inflammation, including leukocyte infiltration and formation of specific key mediators in airway pathophysiology [8]. It is already known that strenuous exercise may induce LX biosynthesis and further metabolism in healthy volunteers [14].

An increase in LX biosynthesis during exercise may have relevant pathophysiological implications. LXs play important role in the resolution of the inflammatory response. Their production in the course of physical exercise may suppress the action of exercise-induced pro-inflammatory mediators [15].

This study shows the role of Lipoxin A4 in exercise induced bronchoconstriction in asthmatic children. In this study, regarding FEV1 and PFER, they were statistically significantly higher in control children than in asthmatic children before exercise. This result is consistent with O'byrne et al., 2008 [16] who reported that pulmonary function tests were abnormally declined in asthmatic children, Severe asthma exacerbation was associated with a more rapid decline in lung function.

There was significant decrease of FEV1 before exercise in asthmatic children with EIB as compared to asthmatic children without EIB but, there was no significant difference between the asthmatic children with EIB and asthmatic children without EIB as regard to PEFR before exercise.

Johansson et al., 2016 [17] reported that lower baseline FEV1 was related to the presence of EIB. While, Fayezi et al., 2015 [18] reported that baseline
PFT to be a poor predictor of EIB, as significant FEV1 decline occurred in some asthmatic children with normal baseline lung function.

Yilmaz et al., 2014 [19] found in their study that variation in airway obstruction is expressed as a change in the one-second forced expiratory volume (FEV1), the quantity of $15 \%$ or more of the predicted FEV1 can be used to identify the asthmatic patients. This degree of change is useful in interpreting both the response to inhaled bronchodilators in obstructed patients and the lability of air flow produced by exercise and bronchodilators in non-obstructed patients. Kang et al., 2008 [20] found that asthma severity classified by symptom frequency or medication usage did not correlate with FEV1, which was generally normal, even in severe persistent asthma. It has been reported that asthmatic children without symptoms have decreased FEF25-75 in a larger proportion of patients than have peak expiratory flow rate or FEV1, suggesting that FEF25-75 is a more sensitive indicator of chronic airflow obstruction. Bacharier et al., 2012 [21] noted that FEV 1 is generally normal in children with asthma, even those with severe persistent childhood asthma, whereas the FEV1/ forced vital capacity ratio decreases as asthma severity increases.

In this study there was significant decrease in FEV1 after exercise as compared to before exercise in asthmatic children. Also, there was significant more decrease in FEV1 after exercise in asthmatic children with EIB as compared to asthmatic children without EIB. There was no significant difference in healthy children as regard to FEV1 between the before exercise and after exercise.

Exercise-induced asthma (EIA) is conventionally defined as at least $10 \%$ or more decline in FEV1 after exercise [11]. Some authors consider $15 \%$ or more decline in FEV1 as the cutoff point to diagnose exercise induced asthma [12]. In this study, we considered exercise-induced asthma as $10 \%$ or more decline in FEV1 after exercise.

Fayezi et al., 2015 [18] reported decline in FEV1 after exercise by $10 \%$ or more in asthmatic children with EIB, most positive responses occurred at about 10 minutes after exercise in $31 \%$ of cases. Cough was the most consistent sign but FEV 1 decline did not accompany any symptom or sign in some asthmatic children with EIB.

In this study there was significant decrease in PEFR after exercise as compared to before exercise in asthmatic children with EIB and also, in asth- 
matic children without EIB. There was no significant difference between the asthmatic children with EIB and asthmatic children without EIB as regard to change (decrease) in PEFR (\% of predicted) after exercise. There was no significant difference in healthy children as regard to PEFR between the before exercise and after exercise.

A $10 \%$ or more decline in PEF or at-least $25 \%$ reduction in FEF25-75 may also be considered for diagnosis of EIB [21], although Weiler et al., 2007 [4] reported that Using of PEF for the diagnosis of EIB is not recommended. Silva et al., 2011 [29] reported that the use of the peak flow meter is an important instrument in the detection, initial diagnosis of EIB in central airways and it can help in the early detection of airway obstruction. Fayezi et al., 2015 [18] reported that there was no significant decline in PEF in about $14 \%$ of asthmatic children with EIB in their study but one limitation in their study was that patients were not categorized on the basis of taking or not controller medications, which certainly could affect the response to exercise challenge.

Akar et al., 2015 [22] compared the percent change PEF and FEV1 in asthmatic subjects. They reported that the criteria to define the normal airway response to exercise are not standard; and, as a consequence, the estimated incidence of EIB in asthmatic children is wide. According to the study, $\mathrm{PEF}$ values can decrease in response to exercise without changes in FEV1 in the mild asthmatic children.

In this study regarding serum Lipoxin A4 (LXA4): There was significant decrease of LXA4 before exercise in asthmatic children with EIB and without EIB as compared to controls. There was no significant difference between the asthmatic children with EIB and asthmatic children without EIB as regard to serum LXA4 before exercise.

Our results were not consistent with $\mathrm{Wu}$ et al., 2010 [23] who found that blood LXA4 in 106 asthmatic children were higher than those of controls. The levels of blood LXA4 were gradually decreased with the severity degree of asthma, meanwhile all values were higher than those of controls. This is suggesting that there are a balance between LX generation and LT production in healthy individuals. Generation of LXs may be proportional to production of LTs. Enhanced generation of LXs could be triggered by overproduction of LTs during inflammatory process.

In a study by Ni et al., 2011 [24]: 69 children were assigned to one of the following 3 groups: acute bronchiolitis, bronchial asthma, or acute gastroenteritis. LXA4 levels were measured in all patients and the lowest levels were detected in patients with asthma, but no significant difference was found among the groups.

Our results were consistent with Gungor et al., 2014 [25] who reported decreased levels of LXA4 and ANXA1 in the wheezing children versus the control group. This was important for understanding the pathophysiology of wheezy infants. Reduced endogenous LXA4 and ANXA1 biosynthetic capability may be one of the reasons for airway inflammation in wheezy infants.

In this study there was significant decrease in serum LXA4 after exercise as compared to before exercise in asthmatic children with EIB and asthmatic children without EIB, with significant more decrease in LXA4 after exercise in asthmatic children with EIB as compared to asthmatic children without EIB. There was no significant difference in healthy children as regard to serum LXA4 between the before exercise and after exercise.

Our results were consistent with Tahan et al., 2008 [26] who observed no significant difference in the pre-exercise lipoxin A4 levels among the asthmatic children with EIB and without EIB. A significant difference was observed in the postexercise lipoxin A4 levels among the groups. They found significant decreases in plasma lipoxin A4 levels immediately after exercise challenge both in asthmatic children with positive responses to exercise and negative responses to exercise, but these levels were significantly higher in asthmatic children with negative responses to exercise.

Inflammatory mediator release can be observed during strenuous exercise, and it is known that this type of exercise can induce lipoxin biosynthesis and further metabolism in healthy volunteers. In a study by Gangemi et al., 2003 [27] a significant increase in LXA4 urinary excretion was observed immediately after strenuous exercise in 9 healthy volunteers.

In our study there was significant positive correlation between serum LXA4 and FEV1. There was no significant correlation between serum lipoxin A4 levels and eosinophil counts and PEFR. There was an inverse correlation between serum LXA4 levels and a reduction in FEV1 after exercise.

Our study results were consistent with Çelik et al., 2008 [28] as they demonstrated that LXA4 levels positively correlated with FEV1 values 
suggesting an association between LXA4 and airway obstruction. As the lipid mediators are potent regulators of airway tone and inflammation, this finding also raises the question about the effect of LXA4 on the remodelling process in lower airways in addition to anti-inflammatory properties, as FEV 1 was known to be directly related to the airway characteristics. Tahan et al., 2008 [26] reported no significant correlation between plasma lipoxin A4 levels and eosinophil counts, total IgE levels, and atopy. There was an inverse correlation between lipoxin A4 levels and a reduction in FEV 1 percent after exercise. Wu et al., 2010 [23] reported that there was positive correlation between blood LXA4 and FEV 1 in the asthmatic children.

In our study: We subdivided asthmatic children into two groups: group (I) included asthmatic children with EIB, group (II) included asthmatic children without EIB. Each group was subdivided into two subgroups; (A) Mild intermittent asthmatic children (B) Mild persistant asthmatic children.

There was no significant difference between the mild intermittent asthmatic children and mild persistant asthmatic children as regard to FEV 1 before exercise with significant decrease in FEV 1 after exercise as compared to FEV1before exercise in both mild intermittent and mild persistant asthmatic children with more decrease in mild persistant asthmatic children.

There was no significant difference between the mild intermittent asthmatic children and mild persistant asthmatic children as regard to PEFR before exercise with significant decrease in PEFR after exercise as compared to PEFR (\% of predicted) before exercise in both mild intermittent and mild persistant asthmatic children with more decrease in mild persistant asthmatic children.

There was no significant difference between mild intermittent asthmatic children and mild persistant asthmatic children as regard to serum LXA4 before exercise with significant decrease in serum LXA4 after exercise as compared to serum LXA4 before exercise in both mild intermittent and mild persistant asthmatic children with more decrease in mild persistant asthmatic children.

These results agreed with GINA, 2018 [3] which reported that children with mild, intermittent asthma constitute more than half of all cases of childhood asthma and asthma severity was inversely associated with pulmonary function (FEV 1), (PEF).More increase in asthma severity was associated with more decrease in pulmonary function.
Wu et al., 2010 [23] reported that blood LXA4 was gradually decreased with the severity degree of asthma (higher level of serum LXA4 in mild asthma than moderate and severe ones).In parallel with the expressions of 15-LO in leukocytes, the levels of blood LXA 4 were gradually decreased with the severity degree of asthma, meanwhile all values were higher than those of controls Blood LXA 4 in 106 patients with asthma were higher than those of controls.

\section{Conclusion:}

There was inverse correlation between serum LXA4 levels and a reduction in FEV 1 after exercise in asthmatic children. The demonstration of lower levels of lipoxin A4 in association with exercise induced bronchoconstriction suggest that the development of exercise-induced bronchoconstriction in asthmatic children may be due to reduced endogenous lipoxin biosynthetic capability.

\section{Acknowledgments:}

This research was carried out without funding.

\section{Conflicts of interest:}

No conflicts of interest declared.

\section{Authors' Contributions:}

All authors had equal role in design, work, statistical analysis and manuscript writing. All authors have approved the final article work.

\section{References}

1- BHAKTA N.R. and WOODRUFF P.G.: Human asthma phenotypes: from the clinic, to cytokines, and back again. Immunological Reviews, Jul., 1, 242 (1): 220-32, 2011.

2- EDER W., EGE M.J. and VON MUTIUS E.: The asthma epidemic. New England Journal of Medicine Nov., 23, 355 (21): 2226-35, 2006.

3- GINA: Global Initiative for Asthma. Global Strategy for Asthma Management and Prevention, Available from: www.ginasthma.org, 2018.

4- WEILER J.M., BONINI S., COIFMAN R., et al.: American Academy of Allergy, Asthma \& Immunology work group report: Exercise-induced asthma. Journal of Allergy and Clinical Immunology Jun., 1, 119 (6): 1349-58, 2007.

5- SERHAN C.N., CHIANG N. and VAN DYKE T.E.: Resolving inflammation: Dual anti-inflammatory and proresolution lipid mediators. Nature Reviews Immunology. May, 8 (5): 349-352, 2008.

6- TANG S., WAN M., HUANG W., et al.: Maresins: Specialized Proresolving Lipid Mediators and Their Potential Role in Inflammatory-Related Diseases. Mediators of inflammation. Apr., 19: 236-69, 2018.

7- PLANAGUMA A., KAZANI S., MARIGOWDA G., et al.: Airway lipoxin A4 generation and lipoxin A4 receptor expression are decreased in severe asthma. American 
Journal of Respiratory and Critical Care Medicine. Sep., 15, 178 (6): 574-82, 2008.

8- BARNIG C., CERNADAS M., DUTILE S., et al.: Lipoxin A4 regulates natural killer cell and type 2 innate lymphoid cell activation in asthma. Science Translational Medicine. Feb., 27, 5 (174): 174ra26, 2013.

9- LANG A., MOWINCKEL P., SACHS-OLSEN C., et al.: Asthma severity in childhood, untangling clinical phenotypes. Pediatric Allergy and Immunology. Sep., 1, 21 (6): 945-53, 2010

10- OKO-OSE J.N., IYAWE V., EGBAGBE E., et al.: Lung function tests in sickle-cell patients in Benin city. ISRN Pulmonology. Jun., 26, 2012.

11- ANDERSON S.D.: The prevention of exercise-induced bronchoconstriction: what are the options? Expert. Rev. Respir. Med., 6 (4): 355-7, 2013.

12- PARSONS J.P., HALLSTRAND T.S., MASTRONARDE J.G., et al.: An official American Thoracic Society clinical practice guideline: Exercise-induced bronchoconstriction. American Journal of Respiratory and Critical Care Medicine May, 1, 187 (9): 1016-27, 2013.

13- KIRKPATRICK L.A., FEENEY B.C.: A simple guide to IBM SPSS statistics for version 20.0. Student ed. Belmont, Calif.: Wadsworth, Cengage Learning; 2013.

14- MARKWORTH J.F., VELLA L., LINGARD B.S., et al.: Human inflammatory and resolving lipid mediator responses to resistance exercise and ibuprofen treatment. American Journal of Physiology-Regulatory, Integrative and Comparative Physiology. Oct., 2, 305 (11): R128196, 2013.

15- TABAS I. and GLASS C.K.: Anti-inflammatory therapy in chronic disease: challenges and opportunities. Science. Jan., 11, 339 (6116): 166-72, 2013.

16- O`BYRNE P.M.: 2007 update of the Global Initiative for Asthma management and prevention: What's new? Polskie Archiwum Medycyny Wewnetrznej. Apr., 118 (4): 179, 2008.

17- JOHANSSON H., NORLANDER K., ALVING K., et al.: Exercise test using dry air in random adolescents: Temporal profile and predictors of bronchoconstriction. Respirology. Feb., 1, 21 (2): 289-96, 2016.

18- FAYEZI A., AMIN R., KASHEF S., et al.: Exerciseinduced asthma in asthmatic children of southern Iran. Global Journal of Health Science. Mar., 7 (2): 115, 2015.

19- YILMAZ O., BAKIRTAS A., ERTOY KARAGOL H.I., et al.: Allergic rhinitis may impact the recovery of pulmonary function tests after moderate/severe asthma exacerbation in children. Allergy. May, 1, 69 (5): 652-7, 2014.

20- KANG B.H., WALSH E.R., SAHU N., et al.: Strainspecific requirement for eosinophils in the recruitment of $\mathrm{T}$ cells to the lung during the development of allergic asthma. Journal of Experimental Medicine. Jun., 9, 205 (6): 1285-92, 2008.

21- BACHARIER L.B. and GUILBERT T.W.: Diagnosis and management of early asthma in preschool-aged children. Journal of Allergy and Clinical Immunology. Aug., 1, 130 (2): 287-96, 2012.

22- AKAR H.H., TAHAN F. and GUNGOR H.E.: The association of forced expiratory volume in one second and forced expiratory flow at $50 \%$ of the vital capacity, peak expiratory flow parameters, and blood eosinophil counts in exercise-induced bronchospasm in children with mild asthma. Asia Pacific Allergy. Apr., 1, 5 (2): 98-102, 2015.

23- WU S.H., YIN P.L., ZHANG Y.M., et al.: Reversed changes of lipoxin A4 and leukotrienes in children with asthma in different severity degree. Pediatric pulmonology. Apr., 1, 45 (4): 333-40, 2010.

24- NI C.M., YANG W. and WAN K.S.: Serum levels of lipoxin A (4) do not predict the development of subsequent asthma among young children with acute bronchiolitis. J. Asthma., 48: 576-580, 2011.

25- GUNGOR H.E., TAHAN F., GOKAHMETOGLU S., et al.: Decreased levels of lipoxin A4 and annexin A1 in wheezy infants. International Archives of Allergy and Immunology, 163 (3): 193-7, 2014.

26- TAHAN F., SARAYMEN R. and GUMUS H.: The role of lipoxin A4 in exercise-induced bronchoconstriction in asthma. Journal of Asthma. Jan., 1, 45 (2): 161-4, 2008.

27- GANGEMI S., LUCIOTTI G., D'URBANO E., et al.: Physical exercise increases urinary excretion of lipoxin A4 and related compounds. J. Appl. Physiol., 94: 2237 40, 2003.

28- ÇELIK GE, MELLIA M, ERKEKOL FO, et al.: Lipoxin A4 levels in asthma: relation with disease severity and aspirin sensitivity. Fundamental and Clinical Pharmacology Aug., 1, 22: 25, 2008.

29- SILVA L.O., SILVA P.L., NOGUEIRA A.M., et al.: Evaluation of exercise-induced bronchospasm assessed by Peak Flow Meter in obese adolescents. Revista Brasileira de Medicina do Esporte. Dec., 17 (6): 393-6, 2011. 


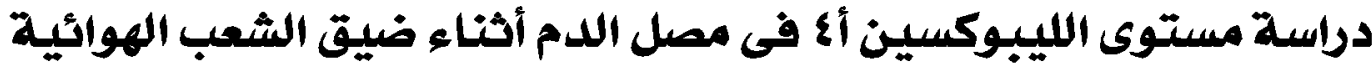

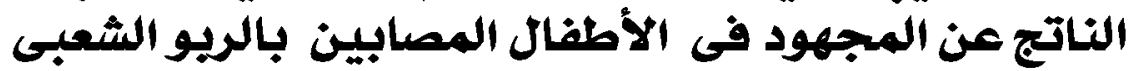

الريب الشعبى هو إلتهاب مزمن فى الشعب الهوائية ويتميز بإنسداد مجرى الهواء، فرط المخاط وفرط الإستجابة فى الشعب الهوائية.

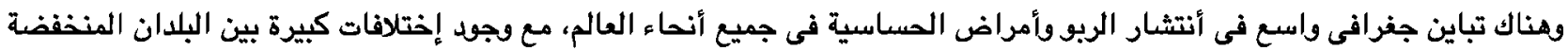

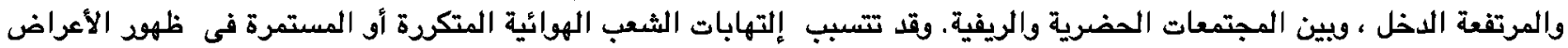

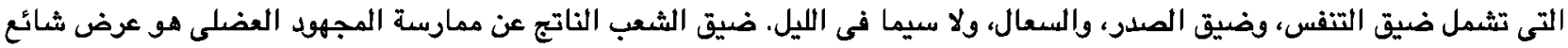

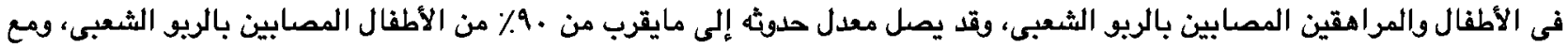

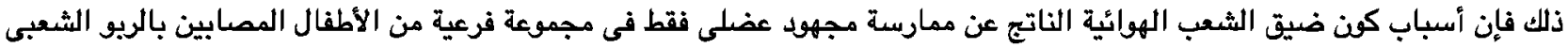

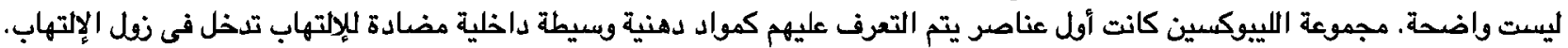

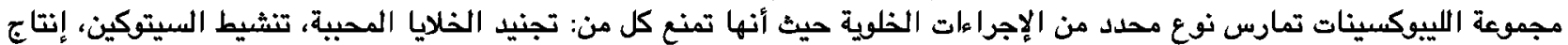

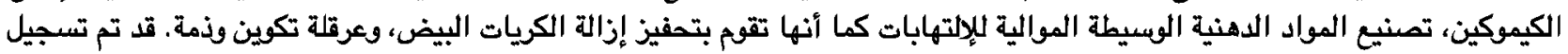

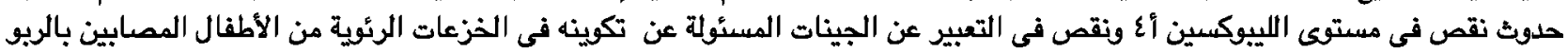

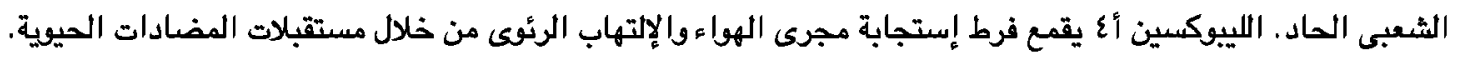

الهدف من الدراسة: قياس مستوى الليوكسين أع قبل وبعد ممارسة أختبار المجهود العضلى لتقييم دودة في ضيق الشعب الهوائية

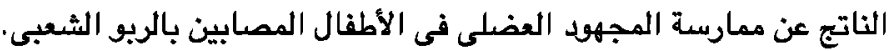

طرق البحث: أجريت الدراسة على ثلاثين طفلا يعانون من الربو الشعبى ويتابعون في عيادة الصدروأمراض الصساسية، بقسم طب الأطفال،

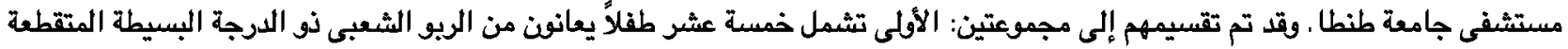

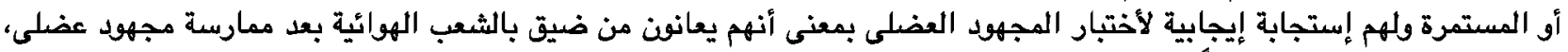

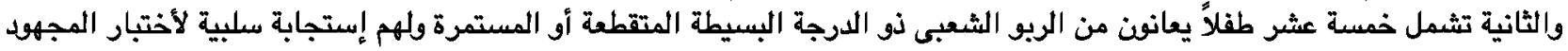

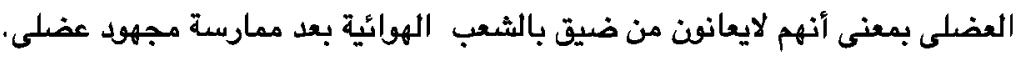

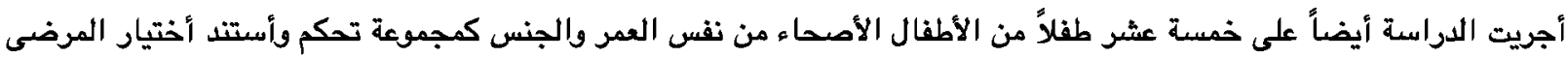

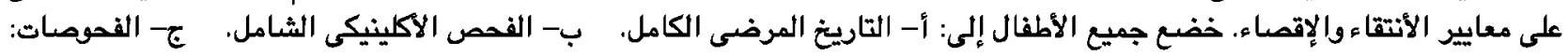

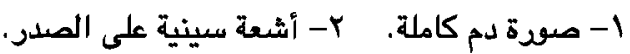
بـ إختبارات وظائف الرئة (ذروة معدل تدفق الزفير والحجم الزفيرى القسرى فى الثانية الأولى) قبل ويعد إختبار المجهود العضلى.

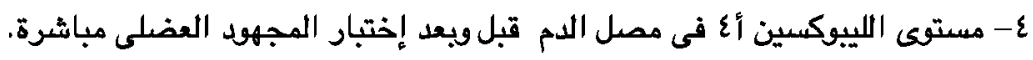

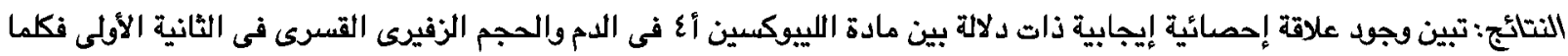

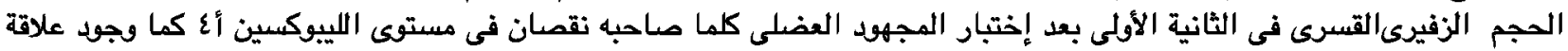

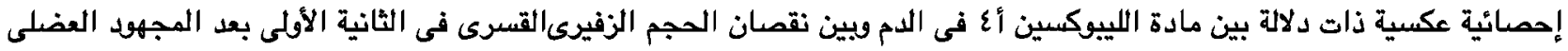

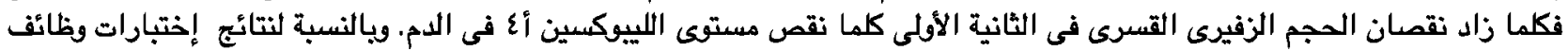

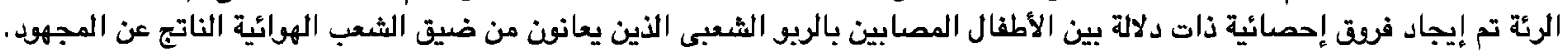

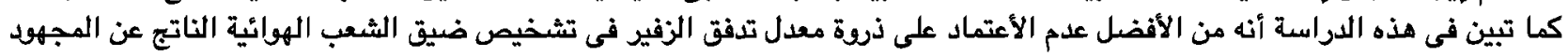

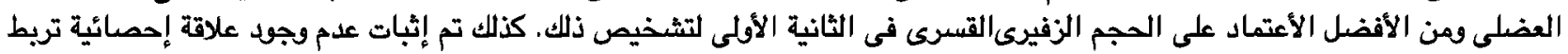

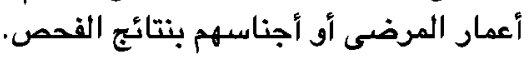

الأستتتاج: ضيق الشعب الهوائية الناتج عن المجهود فى الأطفال المصابين بالربو الشعبى له علاقة بنقص القدرة التخليقية لمادة اللييوكسين أع.

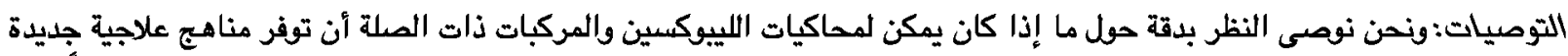

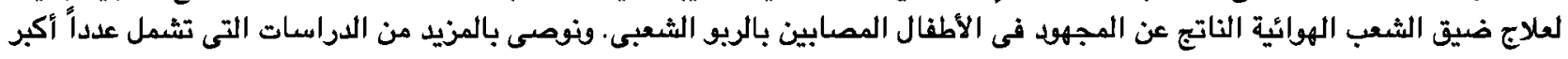

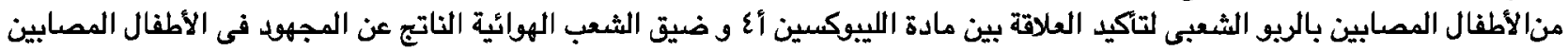

